\title{
A Mythic Journey to Polyphemus, Tepegöz and Grendal
}

\author{
Elmas Sahin \\ Çağ University, The Faculty of Arts and Sciences, Mersin, Turkey
}

\section{Email address:}

elmassahin@cag.edu.tr

\section{To cite this article:}

Elmas Sahin. A Mythic Journey to Polyphemus, Tepegöz and Grendal. International Journal of Literature and Arts. Vol. 3, No. 2, 2015, pp. 12-17. doi: 10.11648/j.ijla.20150302.11

\begin{abstract}
Human shaped, huge sized, sometimes one eyed, three or seven headed giants /monsters are unique folkloric, mythic elements of oral and written cultures and traditions through Greek, Latin, East and West civilizations. From Polyphemus of Homer's classical Odyssey to Anglo-Saxon Beowulf, Turkish Tepegöz (One Eyed-Giant) of the Book of Dede Korkut (Dede Qorqut), Sinbad of Arabic Thousand and One Nights, Fénelon's Telemachus, Joyce's modern Ulysses, even to J.R.R. Tolkien's Norse figures in the Hobbit of our age several mythic adaptations have taken place in Western and Eastern literatures from around the world. Polyphemus, Tepegöz and Beowulf remind of well-known mythic legends built on relationships of heroes and giants of the legends such as Telemachus, Arimaspoi, Kabandha, Psoglav, Jian or one eyed-man eating Cyclops in Sinbad the Sailor etc., In this term, in this study, a comparison of gigantic and heroic figures making a mythic journey to Odyssey, The Story of Basat, Killer of the One-Eyed-Giant (Tepegöz) and Beowulf will be presented to the attentions from a perspective of comparative literature and evaluated their similarities and differences by comparative examples. Here the aim will be to know both the others' and our own works closer, and recognize their impacts and interactions on each other's and also discover their places in the world literature.
\end{abstract}

Keywords: One-Eyed-Giants, Man-Eating Monsters, Mythic Motifs, Comparative Literature, Identity and Patriotism

\section{Introduction}

Comparative literary theory dealing with literatures of different languages, cultures or nations brings to the light a serious of values such as literary, cultural, folkloric and mythic aspects of societies across the boundaries. Comparative investigation or method including examinations of minimum two works as a popular research methods of the age helps us collect some data related to selected texts makes comparisons with regards to form, content, themes, motifs or subjects, between the works having universal importance, evaluates them and introduces the other's literature to us.

Oral and written folkloric and mythic products are the mirrors reflected cultures, traditions, customs, beliefs of the societies from past today. Mythological figures provide large materials for literature, especially epics, legends, fantastic tales, fairy tales fed by mythology are the wealth of the societies. We meet similar mythological elements in folkloric works in Western and Eastern parts of the world. Since Greek and Roman civilizations heroic tales, romantic love, wars, overseas voyages are common themes and subjects, the fights between hero and monster are one of the most significant aspects of the world literature or folklore.
The heroes like Odysseus, Beowulf, Basat, Telemachus or Sinbad, and the other side the giants like Polyphemus, Tepegöz, Grendel or in other words Cyclopes, appear in similar ways in Buddhism, Paganism, Manicheism, Tengriism, Ashurism, Vedism in the system of religious and beliefs of the ancient periods as well as Christian and Islamic mythologies. Together with Greek and Latin civilizations, demonic monsters are narrated very often in mythologies of English, Turkish, African, Asian, Chinese, Japanese, Persian's societies.

While these kinds of legends or folktales are orally passed from one generation to another, they are changed, transformed or adapted to another nation's literary products in various versions. For instance, thousands years later than Homer's Telemachus (before 700 BC), French scholar François Fénelon adapts the story of Telemachus, the son of the King Odysseus in his novel titled Télémaque (1699). Tepegöz assumed that it was written down in $15^{\text {th }}$ century; Beowulf, whose only manuscript is in the British Museum in London, dating from the year 1000 and discovered in the eighteenth century and and Polyphemus of the ancient period have rich mythic aspects with motifs of one-eyed monster and wised heroes. 
A giant as a mythic figure is a species of fairy animal or animal-like human being in world's mythology. The mythic giants are portrayed as powerful, evil, and men-eating animal-like creatures, they are taller and larger than a human being is. They are mostly enemies to people, but they are defeated and killed by heroes after some struggles at the end as in all folkloric tales. When we examine the similarities and differences of these three heroic tales named Odyssey, The Story of Basat, The Killer of One-Eyed Giant (Tepegöz) and Beowulf in concept of the heroes and monsters' relations to each others, in all the tales, the figures of hero and monster takes place in the center of legends as a significant motif. "Depending on the culture, religion and reason for having a giant in a tale, these beings come in a wide variety of characteristics, descriptions, and personalities." (Bane, 2013, p. 159)

Giants play significant roles in the tales, they are symbolized by mostly evil forces, or nature's power. In one sense, the world is turned into some chaos together with an evil Cain committed the first murder by killing his young brother Abel, thus the world is shaped by the struggles of the good and the evil, there are in one-side heroes as protagonist, the other side giants as antagonists. Demonic creatures are descended from Cain, the Angel-like figures are from Abel. Descendants of Abel will defeat the evils and clean from devils, perhaps the first of these fights is reflected by a Vampire demon Ornias in Testament of Solomon $\left(1^{\text {st }}-5^{\text {th }} \mathrm{CE}\right)$ recognized as an Old Testament Pseud-epigraphic catalog of demons. The King Solomon will have all wisdom and all power if the demons subjected by the name of Lord God Almighty. With the ring that the Lord God has sent him, he "shalt lock up all the demons of the earth, male and female; and with their help he shalt build up Jerusalem." (Conybeare, 1997)

Solomon owes his power, wisdom and magnificence to his ring, Tepegöz is also protected by the ring that his mother gave him. In a sense, the good persons are chosen and blessed by the God; however, the evil ones are damned and punished after a while.

When we go back the creation of the humankind, we see in 'devil and man conflict' that these kinds of motifs exist since the first people Adam and Eve. In both Bible and Quran, the satanic figures descended from the Biblical and Quranic Demon or Cain, as if they are delivered the earth from hell, like Satan or Adam and Eve driven out of the Heaven/Eden because of the First Sin. As well as the Quran, in the Old and the New Testaments, the Holy Books, Greek, Roman, English, Turkish, French, Arabian tales have traces of Parables and allusions to the fallen angels/demons being familiar with Solomon-'s authority. Such conflicts between the hero and the devil have been reflected in the mythological or folkloric narratives for many ages from The Book of Dede Korkut and Odyssey to our time.

In this study, these sorts of struggles between the good and the evil in Odyssey and Tepegöz as products of Western and Eastern folklores will be analyzed and evaluated in the light of the comparative literary method. The questions like those that how do these heroines describe? Are their aims the same? What are their similarities and differences? What are the their common features?, will be on the focus of our discussions in the frame of comparative literature through the texts.

\section{A Historical Survey to World Folklore}

The character Tepegöz of the Story of Basat, the Killer of One-Eyed Giant in the Book of Dede Korkut and Grendel of the epic Beowulf are as famous as Polyphemus in Homer's Odysses known to everyone as one of first great works of the world literature. Many ideas have been put forward about that which of them is a pioneer of the folktales. Were the stories of Polyphemus and Tepegöz originals? Were they borrowed from ancient folkloric variants? Which one is the first original legend? One can ask these types of questions, yet we can think what the discovery of their originals gives us or whether or not they have similarities with Grendel; on the other hand, what knowing the answer of these questions provide for comparative literature is quite important as well.

In fact, comparative literature deals with intertextuality similarities and differences, reflections or relationships in the texts rather than answer of the questions; however, literary historian can trace the works as the subject of literary research. Comparative literature does not concern the historical details of the works so much, but a comparatist chooses texts that can be compared or contrasted and have some literary values in terms of universal, and he or she focuses on their similarities, differences or interactions, this is also something that should be. If we turn to texts by the motto." There is no word we have not said under the sky, but the rhetoric/discourse is." In fact, there is no an original thing, except 'discourse'. Who knows, there were another Odysseys as products of oral traditions before Homer's Odyssey or Iliad, what the important is has some meaning for the cultures or societies that they were created or passed behind the boundaries from one generation to the other, and variations or adaptations of the legends or mythic figures have literary values in world literature.

As there are folklorists or scholars claimed that the story Polyphemus was certainly derived from earlier folk variants, there are also scientists who mention that it is the original text of the other variants. German storyteller Wilhelm Grimm prepared one of the earliest investigations by the name of The Legend of Polyphemus (Die Sage Von Polyphemin 1857) on Homer's variant of folktales, he studied its parallels with adaptations of universal oral traditions and commented on foreign scholars' views of the Book of Dede Korkut. Since that time, many similar stories from world folklore have been researched and discovered.

We of course know there are over a hundred folktales of one-eyed, man-eating giants had been collected among different peoples all over the world. (Hackman, 1904). In this sense, Julien d'Huy (2013, p. 5) presents a bigger database including many typological variations of the Polyphemus versions. The data used came from Ojibwa people (Desveaux 1988 : 83), Atsina people (Kroeber 1907: 65-67), Niitsitapi 
people (Wissler et Duvall 1908: 50-52), Kootenays people (Boas 1918: 213-219, 303-304), Jicarilla Apache people (Goddard 1911 : 21), Kiowa people (Parsons 1929 : 21-26), Lipan Apache (Opler 1940 : 122-125), Homer's Odyssey (book IX), a medieval French text (Li romans de Dolopathos written by Jean de Haute-Seille), from Oghuz Turks people (Book of Dede Korkut), Berbers (Germain 1935), PalestinianIsraelian people (Patai 1998 : 31-32), Syrian people (Prym et Socin 1881: 115), Serb people (Karadschitsch 1854: 222-225, Krauss 1883: 170-173), modern Greek people (Athens: Drosinis 1884: 170-176; Cappadocia: Dawkins 1916: 551; Chios: Ludwig 1863: 287-289), Albanian people (Comparetti 1875: 308-310), Ossetian people (Dirr 1922 : 262), Abaza people (Colarusso 2002: 200-202; Dumézil 1965: 55-59), Mingrelia people (Frazer 1921: 449-450), Italian people (Abbruzzo : Nino 1883 : 305-307; Sicilian: Crane 1885: 89), Russian people (Ralston 1873: 178-181; Karel 1907: 38-39), Sami people (Poestion 1886: 122-126), Lithuanian people (Richter 1889: 87-89), Hungarian people (Stier 1857: 146150), Romanian people (Grimm 1857: 15-16), Basque people (Cerquand 1992; Vinson 1883: 42-45; Webster 1879 : 4-6), Gascon people (Bladé 1886 ; Dardy 1884), Swiss people (Abry 2002: 58), English people (Baring-Gould 1890) and West Highlands people (Campbell 1860 : 105-114).

Among them as the most significant example we can give Polyphemus of Odyssey and the Story of Bassat, the Killer of One-Eyed Giant (Tepegöz) and Grendel of Beowulf in the respect to international parallels. While C. S. Mundy (1956) argues that Tepegöz and the other variants are adapted from Greek Odyssey and defends that some episodes from the Book 9 of the Odyssey had been inserted into the story of Tepegöz, the rest of which he considers to be based on an Oghuz folk tale. (Meeker, 1992, p. 396).

Firstly, in 1815 German Scholar H. F. Von Diez ${ }^{1}$ discovered in the Royal Dresden Library manuscripts of the Book of Dede Korkut claims that Homer took Polyphemos from East, perhaps Oghuz Turks of Central Asia. He pays attentions some similarities in the part titled "Der Neuentdeckte Ouguzische Cyklop" (Newly Discovered Oghuzian Cyclops) of his book Denkvürdigkeiten von Asien (Memoirs of Asia) that Tepegöz here looks like another Cyclopes, especially Homer's Cyclopes in all aspects. However, the Oghuz's Cyclops is not received from the Greek's. The Greeks' one is the imitation of it. If it is not outdated in the Greek, that is not new in the Oghuz. (Diez H. F., 1815, p. 416).

Additionally, Grimm also agrees to Diez about that Polyphemus is added to Odyssey later than Tepegöz. Because Tepegöz is told in biographic details, and it is thought that Polyphemus was derived from Tepegöz. In this term, Turkish legend cannot be said that it was taken from the Greeks.

\footnotetext{
${ }^{1}$ The first manuscript of The Book of Dede Korkut consisting of 12 stories is found by German scholar H.F. von Diez in a Dresden library. The second copy with six stories is discovered in the Vatican's library by the Italian scholar E. Rossi, both of them are also dated to the 16th century and written in the Oghuz Turkish.
}

(Sakaoğlu, 1998, s. 95). While Denys Page (1955, 1-22) shares similar ideas with Grimm and Diez in the article titled "Lotus Eaters," C. S. Mundy (1956) argues that some episodes of the Oghuz story of Tepegöz, the very tale which had begun the controversy, had been taken directly from book 9 of the Odyssey. (Meeker, 1992, p. 396). Ofcourse not only Tepegöz and Polyphemus but also Grendel has similar aspects to them. Three of them show several properties of mythic epic poem and story. The shortest of them is the Story of Basat, the longest one is Homer's Odyssey.in nearly 1500 lines.

\section{The Mythic Giants: Turkish Tepegöz, Anglo-Saxon Grendel and Homeric Polyphemus}

Before the stories of Basat, Beowulf and Odysseus or Tepegöz, Grendel and Polyphemus are compared and contrasted, it will be useful to introduce the three legends shortly. Basat's legend who is an Oghuz noble's son is the eighth story in the Book of Dede Korkut. Basat is a hero that saves all Oghuz from one-eyed, and man-eating giant called Tepegöz. While the Oghuz are escaping in the darkness of night during the attack of the enemy, the baby son of Uruz Koja falls from the horse. A lioness finds him and nurses him. Time passes and the Oghuz come back their homeland. The father finds his son, and takes him to the tent. Dede Korkut, the keeper and story teller of Oghuz tradition, says: "Let your name be Basat. I have given you your name, may Allah give you your years of life." (Sümer, Uysal, \& Walker, 2013, p. 123)

However Tepegöz "derived from the words tepe (hill, top, head) + göz (eye)" (Sümer, Uysal, \& Walker, 2013, p. 199) is the illegitimate son of one of the shepherds of Uruz and a Fairy (Peri). One day the shepherd captures one of some fairies and couples her, after that the Fairy says: "Shepherd, I shall have something for you. When a full year has passed, come then and get it. But know that you have brought misfortune to the Oghuz people." (Sümer, Uysal, \& Walker, 2013, p. 123) when the Shepherd hears these words, he is frightened and his face turns pale with anxiety. Time passes and Tepegöz is born as a monster human having one eye at the top of its head." Thus her prediction will be occurred.

As for Homer's Odyssey, the story focuses on the hero Odysseus, his wife Penelope, their son Telemachus, and the mythological giant Polyphemus. The most significant aspect bringing these two legends closer each other is similarity of Tepegöz and Polyphemus. They are mythic evils creatures, but Odysseus and Basat are good and powerful heroes. In the same way, that Tepegöz is the son of a Sea Fairy, (Nymph) and the Shepherd of the Oghuz, he is a half-human, halfmythic creature, Polyphemus is also the son of the God Poseidon (God of the Sea) and Thoosa (a sea Nymph) in ancient Greek mythology. The giant Polyphemus is one of the Cyclopes described in the ninth book of Homer's Odyssey. A Cyclops (plural Cyclopes) means "round eye" in Greek. 
Polyphemus is a one-eyed semi-human giant having a single eye at the center of his forehead like Tepegöz's.

As for Beowulf, which carries its hero's name, is set on the brave man Beowulf and the giant/dragon Grendel and Grendel's mother. The Grendel family has the mythic supernatural aspects. Polyphemus, his father and mother; Tepegöz and his fairy mother; (the mother Fairy is absent after her son's birth) and Grendel and his mother are the supernatural characters. While Polyphemus and Tepegöz live in the caves, Grendel who is one of the unholy brood of monsters, accursed of God, he haunts the moors, the wild marshes, and he is a creature "who dwell in moors, fens, and swamps, remote from God-fearing men, ever bent on doing hell's work of harm and destruction." (Ragozin, 1900, p. 222)

The heroes Basat and Beowulf are apart from Odysseus in one point. They fight with the giants, which pose major threats to their societies. Their goals and ambitions are to save their societies from this man eating dangerous monsters, because of this Grendel, his mother and Tepegöz will be killed by the heroes wanting to bring peace to the societies. Basat grown by a lioness and Beowulf who have superior physical powers risk their own life to save their societies who cannot protect themselves from the monsters. For this reason, we say them "heroes." Naturally, their loves for their homelands, patriotism will be more important than their own lives. However, in Odyssey, the hero Odysseus runs across Polyphemus and the other Cyclopes on an island while he returns his home, the Cyclops Polyphemus eats his some men, and thus Odysseus defeats the Cyclops after he makes him drunk, but he cannot kill Polyphemus, escapes from the island of the Cyclopes.

Paying attention Tepegöz's resemblance and difference to Polyphemus, Michel E. Meeker comments personal identity and social relations/values in Tepegöz story as ethical problems. He thinks that the heroes or heroines in the Dede Korkut Stories sacrifice their personal desires. He argues the characters have no ethic of individualism. "Individuals are always under the constraint of their social and familial obligations. The outstanding feature of these obligations is devotion to others, a devotion that requires the sacrifice of personal desires and ambition and the suppression of personal fear and anxiety. A hero or heroine is time and again strong, courageous, and intelligent in his or her fulfillment of such a social obligation." (Meeker, 1992, p. 412).

Meeker can be right partly, but the individual is free his or her decisions, patriotism is her/his choice, for instance Basat's attempt for killing Tepegöz is an individualist decision. The thought of "Individuals are always under the constraint of their social and familial obligations, this is the result of his patriotism, he will rescue his society from this man eating monster or die. We must accept that this kind of attempt exists in similar ways in almost every society. The characters of age of heroism devotes themselves to happiness and welfare of their nations or societies, they are happy pleased in this way. As a matter of fact, nobody else would want to face to the dangers, or a few brave hearts try to save their countries from terrible situations, but they cannot succeeed, the only the heroes can do it. Is Beowulf not the same? Or Rob Hood, King Arthur or Jeanne d'Arc etc? Are these heroes different from Basat attempting to kill Tepegöz? Certainly Odysseus can be said that he is not a patriot like Basat and Beowulf, we see his some individualist sides as in the scenes of Polyphemus's defeating or his voyage over the seas, but it is also clear so much. The epic of Odysseus is different from Basat and Beowulf's stories in this sense.

As we say above, everyone is not a hero. The heroes of the legends, Basat and Beowulf can kill the giants, as for Odysseus can only blind the eye of the Cyclops. Although Odysseus has got some men with him, they are afraid of the monster, they prefer to escape from there. Odysseus is crafty and clever, but Basat and Beowulf are powerful and fearless in addition to clever, brave men. Nobody can kill the monsters. Neither a sword nor an arrow can cut or injure them, but Tepegöz and Grendel can be killed by the heroes Basat and Beowulf. Tepegöz and Polyphemus's eyes are blinded by Basat and Odysseus, and firstly Grendel's arm is broken, then his head is cut by Beowulf.

In the other side, Beowulf in thirty men-power fights with Grendel without armor and sword in equal conditions, he is unarmed like Grendel. He grasps Grendel's arm behind, he struggles with Grendel until he breaks his arm. Grendel is injured and escapes, Beowulf hangs the giant's claw on the wall of Heorot, then Beowulf will catch and kill him. But there is another danger, the mother Grendel will come for her son's revenge. Nevertheless, after some struggle to the Mother Grendel, Beowulf cuts the head of Grendel's mother, thus he saves his society from the devils.

Like the Bard/Poet Dede Korkut in the Story of Basat, the poet of Heorot in Beowulf also sings songs they all celebrate the victory. On the other hand, Basat in beliefs of heroic Islam and Beowulf in the period of and pre-Christian /Christian are in accordance of Heroic age, they thank the God for helping them. Before Basat kills the giant, He praises and repeats the name of Mohammed by his belief to the God. And he thinks that he has succeeded by the name of God or Mohammed. When Tepegöz asks how Basat has got away from him, he answers: "'Basat said My Allah saved me " (Sümer, Uysal, \& Walker, 2013, p. 129)

Just as Beowulf expressing his gratitude to God looks like Basat in this respect. The religious, social and patriotic motifs are common in both of them, but Odysseus gives no thanks to the God. Probably this is because he is a half-god, as a sea god and nymph's son and he needs no pray or thankfulness. Polyphemus is not killed for the sake of a nation, or a society, but for Odysseus's own sake, it is an individual issue. Odysseus rescues himself and his men by killing the giant.

However, Beowulf's story does not end here, after the King Hygelac's death, firstly Hygelac's son, then Beowulf becomes the king. Beowulf manages fifty years his country. One day a fire-breathing dragon will attack his people. In this time, Beowulf will fight the dragon, he will succeed in killing the dragon, but he will also receive mortal wound, and dies at the end of the story. In this respect, Beowulf is different from 
Basat and Odysseus. Both Tepegöz and Polyphemus are one eyed and man-eating giants, but although Grendel eats menflesh, he is a dragon having the claws, two hands, two legs and a head in animal like and half human shape.

\section{Comparative Approaches to the Mythic Giants and Legendary Heroes}

When we regard the fact that, each mythology borrows myths, motifs and themes from neighboring nations, languages or cultures and each society; and it creates, recreates, changes or adapts mythic elements according to their own culture, beliefs or perceptions, Odyssey, the Story of Basat, Killer of One-Eyed Giant (Tepegöz) and Beowulf as products of nearly the same and similar geographies cannot be thought apart or away from oral traditions transferred from one culture to another.

When we make comparisons between Tepegöz, Grendel and Polyphemus, firstly we recognize both gigantic figures have epic, legendary elements, mythological, supernatural appearances. While Tepegöz is born as a result of the relationship with a fairy, nymph of the shepherd, that is his mother is a nymph, Tepegöz by means of magic ring his mother gave him is protected from the swords and arrows of the Oghuz; he is an animal like creature rather than a human being. In the similar way, Polyphemus is also the son of a both nymph and the sea god Poseidon, and Grendel is a supernatural devil, a successor of Cane. However, Beowulf who is a Anglo-Saxon folk hero is the strongest of his time, a fearless noblman, Beowulf's father is the king Hygelac's brother-in-law who was dead the time the story begins, and Hrothgar's friend, the king of Danes. Basat who lioness grows is also a nobleman warrior of Oghuz, more powerful than everyone is. Odysseus is also equipped by divine as the sea god's son, like Basat and Beowulf.

On the other hand, Tepegöz and Polyphemus having only one eye on their foreheads as man-eating creatures are parallel from various points. One of the most significant resemble is the killing scenes of the monsters. Basat takes the hot skewer in the fire when Tepegöz is sleeping and pushes it so hard into Tepegöz's eye that he completely destroyed it. (Sümer, Uysal, \& Walker, 2013, p. 129)

In a similar way, Odysseus also blinds Polyphemus and kills the monster, and escapes with his men from the Cyclopes' island. Whereas Odysseus offers Polyphemus his strong wine, tricks the monster eating his some men and makes him drunk by the wine. Thus, Odysseus gets a chance to kill Polyphemus falling asleep Odysseus, and to gouge out the Cyclops' eye, which is the only mortal flesh he uses a sharpened club that his men heated. Polyphemus screams in pain like Tepegöz blinded by Basat. The cave scene after blinded the giants' eyes in both stories resembles each other. Tepegöz and Cyclops rush up to their caves, they close the entrance of the caves by huge body and try to catch the person who has hurt him.

One of the most important scenes occurs in front of or in the cave that Tepegöz and Polyphemus have been defeated by the heroes, Basat and Odysseus. Tepegöz stands at the cave entrance, one foot on one side, the other on the opposite side. in order to escape from the cave Basat kills a ram, one of the sheep indoor, at once at skins it, keeping its tail and head intact. He gets into the skin and goes near Tepegöz in the entrance of the cave to go out. But Tepegöz understands that Basat is in the skin of the ram, however Basat succeeds in escaping between his legs. (Sümer, Uysal, \& Walker, 2013, p. 129) There is a similar scene in Odyssey as well. Nevertheless, Odysseus bounds the rams noiselessly in threes together, with some of the withies on which the wicked monster used to sleep. There was to be a man under the middle sheep, and the two on either side were to cover him, so that there were three sheep to each man. As for myself there was a ram finer than any of the others, so I caught hold of him by the back, esconced myself in the thick wool under his belly, and hung on patiently to his fleece, face upwards, keeping a firm hold on it all the time." (Homer, 2003, s. 56). Thus they all are in safe.

When we look at reasons leading the giants/Cyclopes to death, we see they are very dangerous for people, because they are not only animal-eating, but also man-eating creatures. Tepegöz feeds on two men of the Oghuz Turks, and five hundreds sheep a day, Polyphemus also eats Odysseus's men as well as sheep and Grendel and the other demons are like Tepegöz and Polyphemos, they feed on men and animal flesh.

Tepegöz and Polyphemus and the other Cyclopes live in the caves in an Island around Sicily as animal and man-eating giants, additionally Cyclopes grow goats and sheep for their milk, but Tepegöz keeps two men for cooking his meal, he lives alone away people while Greek Cyclopes have wife and children, the giant Tepegöz and the Cyclops Polyphemus are alone.

Tepegöz is remembered for the role of his giant figure, his struggles with the Oghuz in the epic Book of Dede Korkut. $\mathrm{He}$ is the nightmare of the Oghuz. He eats many men of the Oghuz and will dry almost descendants of Oghuz. Because of this, the hero Basat, the most fearless among them, undertakes to kill this man eating giant. However, returning with his crew, on their way home from the Trojan War, Odysseus lands on the island of the Cyclopes for some supplies. We meet the cave scene here as in Tepegöz. In the story Odysseus and his men sees the cave of Polyphemus, and aim to steal some food. Nevertheless, Odysseus is in wondering to see how Cyclopes are like, they wait for in the cave until Polyphemus returns.

Polyphemus believes Odysseus easily about whatever he says, Odysseus says that his name is 'noman', he misleads the giant about the location of his ship, he deceives him the ship is wrecked on the shore, he makes Polyphemus drunk by a trick. When the other Cyclopes hearing the screams of Polyphemus blinded by Odysseus runs to the aid of the giant, ask him who does it, Polyphemus answers 'Noman,' thus the Cyclopes cannot do anything.

"Who is hurting you?" asked the other Cyclopes. "'What 
ails you, Polyphemus,' said they, 'that you make such a noise, breaking the stillness of the night, and preventing us from being able to sleep? Indubitably,, no man is carrying off your sheep? Surely no man is trying to kill you either by fraud or by force?' But Polyphemus shouted to them from inside the cave, 'Noman is killing me by fraud; no man is killing me." (Homer, 2003, p. 56) The other Cyclopes thinking that his screams are punishment from the gods are away there. Odysseus defeats the giant by trickery, but not by force of his arms; however, Tepegöz and Beowulf kill the monsters by force of their arms.

\section{Conclusion}

As a result, when we examine in the light of comparative literature to these three epics with their similarities and differences we become aware of some kinship in Turkish and British culture, folklores and social circumstances rather than ancient Greek traditions. The central motifs are established on struggles of mythic heroes and giants.

In almost all heroic stories even though evil creatures are defeated or killed, the societies' perceptions and approaches are different from each other's. Some is in quest of individual adventures like Odysseus, some are devoted themselves to their homelands like Basat and Beowulf. "The tension between giants and heroes between the competing forces of social order and individual expression, authority and individuality" (Conrad, 1999, p. 228) take place in the works by several descriptions or images, individualism of Odysseus turns into patriotism with Basat and Beowulf.

The mythic, gigantic, supernatural figures such as Tepegöz, Polyphemus and Grendel or the heroic characters like Basat, Odysseus and Beowulf are valuable folkloric, mythic elements of oral and written cultures and traditions for Greek, Oghuz Turkish and Anglo Saxon civilizations, and they are among the most significant works of the world and they are well-known in all over the world. These kinds of literary studies provide huge fields for comparative study, accordingly, the corporatists focusing on international works, examining and evaluating on which perspectives the texts are similar or not from, bring boundaries of universal literatures together, and contribute the world literature. Thus through the comparative literature, texts analyzed come day light in the context of their relations such as motifs, themes, subjects and narratives with each other.

In one sense as I mention earlier, based on the comparison of these narratives with motifs of Polyphemus, Tepegöz and Grendel, the evil figures remind us of maintainers of Cain's parentage who is the first murderer of human being, his brother Abel in the Bible and Quran. The Bible and Quran are told that God punishes them forever for the crime of Abel's death. In Beowulf it is referred to Cain about that Grendel and the other monsters are murderous creatures of "the unblest posterity (so wise men tell) of Cain, the first shedder of innocent blood." (Ragozin, 1900, p. 222) in this respect, Tepegöz, Polyphemus, Grendel and the other Cyclops can also be described as sons of Cain.

\section{References}

[1] Bane, T. (2013). Encyclopedia of Fairies in World Folklore and Mythology. North Carolina: McFarland \& Company.

[2] Conrad, J. A. (1999). Polyphemus and Tepegöz Revisited A Comparison of the Tales of the Blinding of the One-eyed Ogre in Western and Turkish Traditions. Fabula, Volume 40, Issue 3-4, 278-297.

[3] Conybeare, F. C. (1997). The Testament of Solomon translated. Trns. by F. C. Conybeare: This digital edition by Joseph H. Peterson,

http://www.esotericarchives.com/solomon/testamen.htm.

[4] d'Huy, J. (2013). Polyphemus (Aa. Th. 1137) A phylogenetic reconstruction of a prehistoric tale. Nouvelle Mythologie Comparée- 1, 1-21, https://hal.archives-ouvertes.fr/hal00826004/document.

[5] Diez, H. F. (1815). Der Neuentdeckte Ouguzische Cyklop. In H. F. Diez, Denkvürdigkeiten von Asien (pp. 416-457). Berlin und Nalle.

[6] Hackman, O. (1904). Die Polyphemsage in der Volksuberlieferung. Helsingfors. Finland: Frenckellska.

[7] Homer. (2003). Odyssey. Trans. Samuel Butler: Project Gutenberg,

http://s3.amazonaws.com/manybooks_pdf_new/homeretext99 dyssy10?AWSAccessKeyId=AKIAITZP2AAAM27ZGISNQ\& Expires $=1429128429 \&$ Signature $=$ VOga0QAXKKER1Bv013 CxByjKORA\%3D.

[8] Meeker, M. E. (1992). The Dede Korkut Ettic. Int. J. Middle

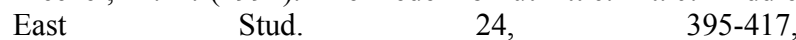
http://www.learningace.com/doc/5459460/5991d25d11df6fb6 085cfde63186ae86/dede-korkut-ethic-1992-meeker\# .

[9] Mundy, C. S. (1956). Polyphemus and Tepegoz. BSOAS , 18:2, UAJb 29: 1-2, pp. 279-302.

[10] Ragozin, Z. A. (1900). Beowulf, the Hero of the AngloSaxons. New York: William Beverley Harison.

[11] Sakaoğlu, S. (1998). Dede Korkut Kitab1: İncelemeler, Derlemeler, Aktarmalar. 1. cilt , Konya: Selçuk Üniversitesi Yaşatma ve Geliştirme Vakfı Yayını.

[12] Sümer, F., Uysal, A. E., \& Walker, W. S. (2013). The Book of Dede Korkut: A Turkish Epic. Translated and Eded From Turkish to English, Texas: University of Texas Press. 